\title{
Sustainability issues in ports: content analysis and review of the literature (1987-2017)
}

\author{
Nergis Özispa ${ }^{1}$ and Gamze Arabelen ${ }^{2 *}$ \\ ${ }^{1}$ Dokuz Eylül University, Maritime Faculty, Department of Maritime Business Administration, İzmir, \\ Turkey \\ ${ }^{2}$ Dokuz Eylül University, Maritime Faculty, Department of Maritime Business Administration, İzmir, \\ Turkey
}

\begin{abstract}
Sustainability, which has environmental, social and economic dimensions, is a phenomenon that has been used extensively in recent times. As decided in Brundtland Conference in 1987, it basically aims to meet the needs of the present without compromising the ability of future generations to meet their own needs. When it is taken into consideration in terms of sustainability, it is known that ports are one of the most polluting sectors due to their nature. However, in recent years many ports have started to different sustainability programs and invested in large amounts over the years to reduce emissions and to gain a competitive advantage. When examined the past studies, it is determined that the sustainability concept is a relatively recent approach in the maritime literature and still a gap exist in this field. It is thought that the analysis of these studies in a systematic way will contribute to the port sustainability literature. Therefore, in this study, it is aimed to review port sustainability concept with the help of existing literature. For the methodology, studies obtained from different databases were evaluated systematically by using content analysis. The study has been concluded with the findings for the related literature, recommendations for the sector and guidelines for future researches.
\end{abstract}

\section{Introduction}

The sustainability concept is based on forestry, fisheries and soil science and associated with the concept of productivity in the fields of renewable sources like agriculture ecology and fishery [1] and it has been described as "ability to maintain productivity despite obstacles" [2]. The concept of sustainability has been defined in diverse fields like management and social science, environmental science or technical science [3], but the most adopted definition of sustainability was made in Brundtland Report for the World Commission on Environment and Development in 1987 as; "Meeting the needs of the present without compromising the ability of future generations to meet their own needs" [4]. Sustainability concept consists of three dimensions which are; environmental, economic and social, and these three dimension

\footnotetext{
* Corresponding author: gamze_arabelen@hotmail.com
} 
also referred as the triple bottom line of sustainability [5]. These three value driven dimension are visualized and help monitor the port sustainability performance [6].

Ports are very complicated because of their nature, various services and a wide range of environmental issues such as water releases (limber water), harmful emissions, waste and noise production and pollution $[6,7]$. They are composed of different companies, dealing with different activities and offering a wide range of services. Seaports are notorious to be serious polluting industry, however, they have many opportunities for reducing emissions and pollutions [8]. Sustainability in the port industry is of growing source of fear for port authorities, policy makers, port users and local communities [9]. Therefore, sustainability is one of the important concepts for port industry and it was thought that more detailed examination would be useful. Accordingly, the aim of the study is determined as to contribute to the literature by systematically analyzing port sustainability studies published in various databases. To address this aim, the rest of this paper is organized as follows. Port sustainability literature in different databases is reviewed in the following section. Subsequently, the data collection, the method used to analyze studies and the results are described. Finally, we discuss the results in terms of their implications for practical and scientific, and their limitations and directions for further researches.

\section{Literature review}

\subsection{Sustainable development}

When analyzed current literature in port sustainability concept, it is seen that most of the studies is written on sustainable development subject. Starting with Daamen's (2007) study that investigate port sustainable development in two different geographies which USA and Europe aiming to find a new typology and new interpretation of the contemporary port-city interface [10]. Same year Abood made a case study at New York port and demonstrate several examples to show how to fit more advanced programs into a sustainability framework. To limit sustainability subject, Abood used eight port operational topics which are; dredging, ballast water, habitat restoration, air quality, water conservation, energy conservation, material conservation and waste handling, and used them as sustainability perspective. At the end of the study Abood proposed a more quantitative sustainability rating system specifically designed to deal with port activities [11]. In (2012) Lam and Van de Voorde made a case study with 4 ports that the port of Los Angeles, Long Beach, Antwerp and Hong Kong to fill the gap in the concept of green and sustainable port strategy by formulating a new framework. Hence an original framework and propositions have been developed in green and sustainable port strategy as findings of the study [12]. Jonathan et al. (2014) made a literature review to propose a sustainable port project planning model while adding specific components to the basics of sustainability. Their model collected all individual components of sustainability concept into one roof for port project planning (PPP) [13]. Hosseini et al. conducted survey to 381 people at Torkaman city to acquire relatively exact description of condition of urban sustainable development from citizens' rights point of view in 2014. At the end of the study they determined most and least effected identifiers on sustainable development of Torkaman port city which is respectively civil rights and political identifiers [14]. Kutkaitis et al. (2014) conducted interviews with specialists and consultants of port and logistics sector practitioners to identify the criteria of port sustainable development. As a result, they designed seven steps that determine sustainability of Port of Klaipeda's logistics activity. Hence they prepared a set of indicators that determine different levels of sustainability of ports [15]. In addition, in 2014 Martino created an alternative managerial perspective in the decision making process of port authority using the literature review 
method [16]. In the year of 2015 Wang et al. investigated energy efficiency of port operations in their case study, aiming to improve energy efficiency with financial success, to report the effectiveness of sustainable development policy and to highlight the workable plans for ports in China. Finally, they reported a framework of assessing energy efficiency of port operations in China based on the data from public domain by using the combination of DEA (Data Envelopment Analysis) and PDE (Panel Data Estimation) methods [17]. Case study method was also conducted by Boulos in 2015 in Port Said to propose a model framework for sustainable city-port connectivity. In order to develop that model framework, they investigated the development of port-city relationship. As a result of study Boulos emphasized the importance of the balance of both port and city growths. While port expand and modernize, its impacts of the origin settlements (port cities) should be studied for each unique region as well [18]. In 2016 two different studies were published in the subject of port sustainable development. First of them belongs to Laxe et al. With the aim of using the Synthetic Indexes of sustainability in the analysis of port sustainability they examined 16 Spanish port authorities' datum with literature review method. Thus they demonstrated how the ports that have higher Synthetic Indexes on Sustainability move more goods at their facilities than the rest. According to their findings ports that have higher Synthetic Indexes pay more attention to a global and integrated management while being very attentive to both demands of users and permanently adapt themselves to new conditions of international competition [19]. In (2016) Roh et al. conducted in-depth interviews with Asian port authorities to determine the main factors that shaping sustainable port development. As a result, they identified key elements of sustainable port development from port authorities' perspective [20].

\subsection{Sustainability performance}

Sustainability performance is the second important subject in port sustainability literature according to current literature review. Nine study published in port sustainability performance subject in the last 30 years. However, it should also be noted that, even the sustainability concept was born in 1987, the papers about sustainability performance of ports written between the years of 2008 and 2017. First, Hakam and Solvang used case study method on Narvik container port in 2009 to link flexibility and sustainable advantages together in the context of container ports. According to Hakam and Solvang to increase the container port's flexibility one should increase the port's economic and environmental sustainability [21]. Hakam and Solvang also conducted a literature review study about container ports sustainability in 2013. They examined 334 papers to look at port-related initiatives and gain a better insight on market trends about container ports sustainability. Their results demonstrated that sustainability performance and port sustainability has domination on literature between 1985 and 2012. With this study they revealed that the environmental dimension of sustainability seen as an opportunity to improve performance not as an expense anymore [22]. In 2013 Lirn et al. used multi-criteria decisions making methods to measure a port's green performance and choose three major container ports from China as sample. As a finding of study they determined three most critical sustainability indicators chosen by respondents in two of three ports investigated, chosen indicators are respectively; avoiding pollutants during cargo handling and port maintenance, noise control, and sewage treatment [23]. Elzarka and Elgazzar (2014) used three methods which are multicriteria decisions making, survey and literature review with the purpose to propose a performance measurement system to evaluate and improve green performance of ports. As a result of the study they designed a green port performance index using a weighted averaging aggregation method. With this single index a port can compare its overall performance with other competitive ports [24]. In 2015 Hakam published a study about Nordic container ports 
sustainability performance. The aim of that study is to propose a conceptual sustainability performance management framework for container ports. Hence as a result of the study Hakam developed a prototype based on hypothetical data and suggested a list of key port sustainability performance indicators list [6]. Asgari et al. (2015) also used multi-criteria decisions making methods to measure sustainability performance of UK major ports. The main aim of that study is to investigate 5 largest ports in UK sustainability performance according to environmental and economic aspects of sustainability [25]. In $2016 \mathrm{Lu}$ et al. aimed to examine the effects of sustainable supply chain management on sustainability performance in the port context. To achieve this purpose, they conducted survey with 132 respondents who is supervisor or above in three major international port authorities in Taiwan. Studies results demonstrated that external sustainable collaboration is positively associated with internal sustainable management, and internal sustainable management positively influences sustainability performance [26]. Çağlar (2016) used three methods which are interview, survey and literature review in Turkey and USA, aiming to demonstrate sustainable advancements and challenges in efficient and sustainable container terminal operations. As a result, Çağlar emphasized the importance of connectivity of seaports from railroads and gate technologies to approach channel depth and even customs regulations. Study also mentioned advance technology in container terminal equipments as a crucial point of value creation in terms of sustainability of ports [27].

\subsection{Sustainable management}

Port sustainability issues are also studied in management subjects. In this study eight study found written in sustainable management subject. First, Denktaş Şakar and Karataş Çetin integrated the organizational relationships between supply chain and port stakeholders with the aim of providing a conceptual framework based on the socially responsible marketing in 2012. Managerial implications and port authorities' roles in different dimensions of sustainability and framework that demonstrate supply chain stakeholder's influences on port sustainability are obtained as two important outcomes of study [28]. Broesterhuisen et al. (2012) aimed to make a procurement process at ports as sustainable as possible. To reach that aim and to develop a tool, method or model that used by all stakeholder easily interview method was conducted. As a result of study, even they found consensus about some topic, they also found disagreement so many topics. For instance, while air quality is the number one topic in the several sustainable initiatives of international ports, most respondents did not mention air quality as an important criterion for sustainability. Hence they suggested that more research needs to be done about this subject to obtain some reliable and valid results [8]. In $2014 \mathrm{Kim}$ and Chang conducted interviews in Busan Port to guide ports to implant sustainability practices into operations of ports. As a result of study, they identified four important work processes that would improve sustainability performance of ports if conducted better. These processes are listed as; container traffic growth, low environmental impacts and corporate responsible image making, operational efficiency, efficiency use of the port area. They also proposed the simultaneous implementation of those business processes that improved sustainability [29]. Fedai and Madran conducted both case study and interview methods to two different marinas in Turkey in Antalya in 2015. Sustainability issues of ports are examined and sustainable management strategies are mentioned in this comprehensive study. At the end of the study Fedai and Madran found lack of sustainable management perspective in ports and marinas as a mainstream management approach in studied marinas in Turkey, Antalya [30]. Dynamics in sustainable port and hinterland operations was examined by Hou and Geerlings in 2016 with the combination of literature survey, interview and case study methods. They aimed to present a conceptual framework and simulation of sustainability measures and its effectiveness. In that study they considered 
sustainable port related hinterland transport as an organizational issue and they conclude that the greatest challenge for a port to reach sustainable management standards is not to develop new technology but to develop new management regulations [31]. In 2016 Sislian et al. aimed to review the maritime literature of two interrelated concepts which are Port Sustainability and Ocean's Carrier Network Problem (OCNP), they first reviewed the port sustainability concept and then relate it to the OCNP, to integrate port sustainability indicators in the OCNP as a conceptual framework. Findings of this study revealed that the most common sustainable development measures focus on environmental measures hence they suggested that the future researches should focus triple bottom line of sustainability also [5]. In 2017 Wang et al. aimed to develop a conceptual model for the Chinese oil ports in the sustainability policy framework. At the end of the study they contribute current literature with two outcomes. First they developed specific measures to assess oil port sustainability and a holistic oil port sustainability framework [32].

\subsection{Port construction}

Sustainable port construction is also an important and mostly studied subject in port sustainability literature. Between the years of 2003 and 2016 several papers published about sustainable port construction. First, Dooms and Macharis conducted in-depth interviews and multi criteria decision making methods in 2003 to present a conceptual framework for inland port planning which takes into account stakeholder preferences and objectives, in order to realize sustainable port development. As a result, they proposed a framework to develop a strategic Master plan with the port authority of the Port of Brussels [33]. Then, in 2010 Girard aimed to discuss under what conditions port areas can become an opportunity for the whole city development and how could it be possible. Girard used and suggested strategic implementation and management planning in order to combine tangible (hard) and intangible (soft) values in this study [34]. Wahab et al. (2011) used multi criteria decision making, survey and case study methods to ensure a set of standards and technical criteria during construction, design and operation processes of maritime and harbor structures. With developing an integrated sustainable port construction model Wahab introduced a new methodology to assess constructability and operability of port building designs [35]. In (2014) Megahead aimed to outline an approach for exploring the architectural styles of Port Said and proposed the challenges and opportunities for sustainable development in that study. Interviews with 63 residents, 18 planners and architects were conducted in the scope of the study. As a conclusion of the study the importance of building heritage together with environmental, economic and social aspects of sustainability as a main concern on any sustainable development emphasized [36]. A case study conducted on Port of Koper in (2014) by Pavlic et al. and they aimed to provide a methodological approach to solve the problems of future development challenges of seaports like implementing the green port concept in current infrastructures of ports. As a finding of the study they demonstrated the importance of state-of-the-art technologies, developing pilot initiatives based on modern energy solutions, improve efficiency in fuel consumption and emissions reduction in rubber tired gantry cranes and improve the overall energy efficiency improvement based on testing based on the case studied port [37]. Awad-Nunez et al. published two interrelated study in 2016. Multi criteria decision analysis (MCDA) and case study methods conducted both studies samples that consist of 10 different dry ports. They aimed to research different variables that influence sustainability of dry port location. Consequently, they found the most significant variables effect sustainability which is related to environmental protection [38].

\subsection{Environmental sustainability}


Even though environmental sustainability is just one feature of triple bottom line concept of sustainability, it is the most studied one in the current literature. In this study 5 publishing in the concept of environmental sustainability, are examined according to their aims, methods and findings chronologically. In (1999) Hoyle has examined some projects designed to measure urban coastal change processes and models in Canadian port cities, the influence of process and modals on the community groups. Hoyle conducted interviews with some community groups in selected Canadian port cities in the scope of this study. Study revealed that there is a clear distinction between geographical, area-based or neighborhood groups [39]. Vujicic et al. worked on zero emission cargo handling equipments in 2012. Presenting and evaluating the up-to-date trends in the cargo handling equipment (CHE) industry was the main aim of their study. Reducing the environmental impact of container terminal operations and contributing to the sustainability of ports was another aim of this study. As a result of the study they concluded that electrification system of cargo handling equipments is a step forward to reduce the environmental impacts of ports and it is found as feasible and sustainable solution by the authors of the study. In addition, they also found that zero emission objective in cargo handling equipments are impossible to achieve yet [40]. In (2013) interviews with 5 ports and 2 local government-based harbor authorities are conducted by Dinwoodie et al. to analyze the smaller port authorities' ways to manage environmental sustainability in Southwest England. Dealing with smaller ports became their motivation unlike the current literature and as an outcome they provided a different perspective on environmental management in ports. They revealed that larger ports offer much more revenues compared to smaller ports as a matter of course for that reason it is impossible to transfer application of current environmental management systems that prepared to large ports to smaller ports. At the end of the study necessity of preparing new environmental management systems for smaller ports are emphasized [41]. Borriello et al. (2013). conducted a case study on Valencia port as a successful sample on environmental port management issues and aimed to adapt its management strategies in other port cities and port areas especially in the Southern ports of the Mediterranean. As a result of the study necessity of new integrated evaluation tools for managing the conflict between the port areas and the port cities emphasized [42]. Lastly, a case study conducted on Port of Koper in (2015) by Beskovnik and Bajec with the aimed to identify environmental initiatives and measures that affect sustainability of ports. Study introduced a new six pillar environmental sustainability model that could be used environmental measuring in the region. The outcomes of the study intend to help port management for faster implementation of environmental and social objectives and measures in order to follow sustainable development [43].

\subsection{Sustainability indicators}

Port sustainability indicators used for measuring port sustainability and sustainable development of an industry, in addition it is important to mention that "Indicators" and "metrics" are interchangeably words used for referring to measurement of sustainability, yet somehow term of "indicators" used more broadly in current literature (44). Hence term of "indicators" used in this study instead of "metrics" and 4 studies in the concept of sustainability indicators, are examined according to their aims, methods and findings chronologically. Peris-Mora et al. (2005) published first article in this subject and they developed system of indicators for sustainable port management with the combined use of multi criteria decision making and case study methods. Port of Valencia was chosen for case study, other Spanish and European ports are chosen for Multi Criteria Analysis (MCA) in the scope of the study. Aim of the study was to propose a system of sustainable environmental management indicators that can be used by any port authorities finally they proposed 17 system indicators as an outcome of the study [45]. In 2014 Puig et al. aimed to develop a new 
methodology which is user-friendly to encourage port authorities to adopt the selected indicators within their environmental program. To reach this aim they conducted focus groups, survey, literature review methods, conferences and workshops. As an outcome to assist port authorities in reporting and calculating the proposed indicators, a user friendly tool has been developed. List of indicators grouped in two categories. First qualitative indicators category consists of nine components of environmental management that measure the Port Authority's ability to deliver compliance and effective environmental protection, second quantitative indicators category designed to measure of the actual impact related to specific aspects, namely Carbon Footprint, Waste Management and Water Consumption [46]. Bergmans et al. (2014) conducted a case study method to Port of Antwerp and aimed to examine the port of Antwerp's sustainability reporting initiatives, sustainability reporting performance of the harbour community and process. According to the study that kind of initiatives helps to create new discursive spaces, new practices and new reporting standards but also they contribute to the creation of community identity. Hence it is found that discussing and negotiating sustainability indicators is the way of reaching desired futures of an ideal harbour community [47]. The last study of sustainability indicators subject is published by Shiau and Chuang in 2017. The main aim of that study was to develop an indicator generator to generate initial port sustainability indicators (PSIs). After conducting case study and interview methods in Keelung Port it is suggested that 34 expert based PSIs for the scientific, operational, public relations and non-professional frame in the scope of this study [48].

\subsection{Sustainability policy and coastal development}

Sustainable policy and coastal development subjects are also studied in port sustainability concept. First Gilman studied in port sustainable policy concept in 2003. The main aim of the study was to decide in which Government's strategic objectives could be achieved in the scope of a private port system for the infrastructure, economy and environment. At the end of the study as the workability of the development approval process, the impact of the new approaches, the principle of clear need and particular problems of integration with in inland modes four main issues have emerged [49]. The other study in the concept of port sustainable policy conducted as multi case study with European and American port authorities by Kotowska in 2016. The article aimed to demonstrate port authorities' roles in creating sustainable growth. As an outcome of the study the actions taken by ports to improve the port environment and promote the modal shift have been grouped by author [50]. In 1998 Turner et al. studied the concept of sustainable coastal development for the first time, to decide main forces that influence the development of coastal areas. Consequently, they revealed the need for more open, flexible, integrated and participatory approach to coastal science and management to reduce the inevitable uncertainties [51]. The other study in the concept of sustainable coastal development was conducted by Yap and Liam in 2013. Research aimed to examine ports growth paths and sustainability issues in coastal development. Hence the study contributed to current literature by addressing the need for a balanced approach in sustainability for port and coastal development both political and research subjects [52].

\subsection{Economic and environmental sustainability, ecological footprint, social sustainability, sustainability reporting and measurement}

Economic and environmental sustainability, ecological footprint, social sustainability, sustainability reporting and sustainability measurement subjects also studied in the current literature, there has been found just one study for each. In 1999 Tindall published an article in social sustainability subject, using the the survey method aimed to examine the attitudes, 
opinions, and perceptions of Port Alberni residents and Anti-Environmentalism Movement organization members. After several analyses it is found that the general public is more likely to acknowledge ecological limits, and to be more open to change than members of AntiEnvironmentalism Movement organization [53]. Soler et al. studied about port sustainability reporting subject in 2009. Study aimed to develop sustainability reporting guide standards for the Spanish port sector to satisfy the requirements of stakeholder groups. Study also considered indicators that defined in the Spanish Port System Balanced Scorecard and defined a set of information including ecological, financial and social variables as nonfinancial indicators and financial indicators [54]. A case study conducted on a port in Northern China (2015) by Guo et al. in ecological footprint subject with the aimed to build a port ecological footprint model, considering biological resource, energy and construction land ecological footprint while transferring resources and energy consumed in port production and operation to four ecological productive lands. Consequently, the model could demonstrate port ecological carrying capacity and provide a basis for evaluating the ecologically sustainable development of port but also because of nature of ports waters are accepted as the main sources of port ecological carrying capacity, hence study suggested strengthen the protection of waters to ensure sustainable development of ports [55]. Laxe et al. studied on economic and environmental dimensions of sustainability in 2015. Statistical analyses conducted on 16 Spanish ports sustainability reports to enable the existence of links between ports economic and environmental indicators. After analyzing data, it is found that not all Port Authorities fulfill the requirement specified in the Port Law, just four ports sustainability reports having a series of indicators of sustainability. According to study results to carry out the establishment of penalties to those entities not fulfilling the requirement or showing a negative evolution in these indicators have suggested [56]. Finally, a case study conducted on Singapore Port in (2017) by Xiao and Lam in sustainability measurement subject aiming to narrow the gap between adopting the systems theory and to develop a systems framework for sustainable development using three aspects of sustainability. According to analysis results, study demonstrates that there is a positive relationship between the port and the city, hence study arrived the result of Singapore port could keep on developing by reducing the negative relationships environmentally while increasing the positive relationships economically and socially [57].

\section{Content analysis}

Content analysis is a widely used qualitative research method that uses a set of procedures to make valid inferences about the senders or audience of the message or message itself (58, 59). It is used for, to analyze written, verbal or visual communication messages (60). According to Mayring (2000), qualitative content analysis is "an approach of empirical, methodological controlled analysis of texts within their context of communication, following content analytic rules and step-by-step models, without rash quantification" [61]. Content analysis was first used in the 19th century as a method for analyzing newspapers, magazine articles, advertisements and political speeches [62]. According to Hseih and Shannon (2005), there are three different approaches of content analysis; conventional, directed, or summative. They differed from each other features like; timing of defining codes or keywords, source of codes or keywords and the main motivation to start study. Summative content analysis will be conducted in this study. In summative content analysis, study starts with keywords, these keywords are identified before or during data analysis and they derived from interest of researchers or review of literature [63].

In this study, content analysis will be carried out by examining the studies on sustainability in the ports. Hakam and Solvang (2013) define the aim of content analysis as to summarize existing researches by identifying patterns and issues [22]. To reach that 
specific aim, first studies are collected regarding their main subjects. To obtain an overview of the increase of writings on the topic, an online search was made in the following electronic databases: Google Scholar, Ebscohost, Proquest, Science Direct and Scopus. The search terms "port sustainability", "sustainable port", "environmental management in ports", "green port", "sustainable supply chain management", "corporate social responsibility in ports" and "port sustainable development" are used on all databases in English and Turkish from the period of 1987 to 2017 April. These seven keywords are shown in below Table 1 .

Table 1: The Search Keywords

\begin{tabular}{cl}
\hline Number & \multicolumn{1}{c}{ Corresponding Keyword(s) } \\
\hline $\mathbf{1}$ & Sustainable Port (Sürdürülebilir Liman) \\
$\mathbf{2}$ & Port Sustainability (Limanlarda Sürdürülebilirlik) \\
$\mathbf{3}$ & Environmental Management in Ports (Limanlarda Çevresel Yönetim Uygulamalart) \\
$\mathbf{4}$ & Green Port (Yeşil Liman) \\
$\mathbf{5}$ & Sustainable Supply Chain Management (Sürdürülebilir Tedarik Zinciri Yönetimi) \\
$\mathbf{6}$ & Corporate Social Responsibility in Ports (Limanlarda Kurumsal Sosyal Sorumluluk) \\
$\mathbf{7}$ & Port Sustainable Development (Limanlarda Sürdürülebilir Gelişme) \\
\hline
\end{tabular}

While conducting the scan, search was limited with some criteria. As a source, articles and conference proceedings are included. There also has a time limit in the search criteria. As mentioned before, sustainability concept was born in 1987 Brundtland Report [64], so the literature between 1987 and 2017 was screened. 5 databases were used that free Access provided by Dokuz Eylül University. All scans were carried out in the title of paper, with "containing all of the words" condition. Each keywords and their relevant paper count are given in Table 2 for each database.

Table 2: Number of Studies Available in Port Sustainability Related Publications from Different Electronic Databases

\begin{tabular}{|c|c|c|c|c|c|}
\hline Keyword(s)/Databases & 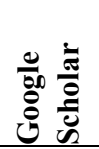 & 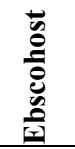 & 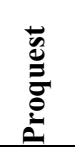 & 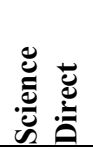 & 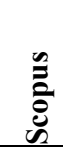 \\
\hline Sustainable Port & 58 & 8 & 7 & 21 & 15 \\
\hline Port Sustainability & 74 & 11 & 5 & 28 & 44 \\
\hline Environmental Management in Ports & 17 & 6 & 3 & 11 & 0 \\
\hline Green Port & 125 & 5 & 6 & 20 & 20 \\
\hline Sustainable Supply Chain Management & 1.245 & 362 & 167 & 216 & 321 \\
\hline Corporate Social Responsibility in Ports & 4 & 0 & 0 & 1 & 0 \\
\hline Port Sustainable Development & 77 & 5 & 7 & 7 & 1 \\
\hline
\end{tabular}

As shown in Table 2, the number of studies on port sustainability issues is quite limited compared to the number of studies on issues like "sustainable supply chain management" or "green port". Considering this gap in the literature, in current study a detailed analysis was carried out with the keywords "sustainable port" and "port sustainability" in databases shown in Table 2. Each study group under the "port sustainability" and "sustainable port" headings 
in Table 2 has been examined separately and the studies that scanned in more than one database have been separated. In this instance studies which are not completely suitable for the scope of this study according to their subjects have been excluded to ensure the reliability and internal validity of the research. 53 papers selected at the end of the scanning period, which are appropriate for the criteria determined, and they were examined in terms of "research subject, type of research and data analysis methods. Detailed information about these 53 studies are given in Appendix 1.

The detailed scanning of the databases includes articles and conference proceedings which include the whole words of "sustainable port" and "port sustainability" in the title of the study and published between 1987 and 2017, the year in which sustainability came into being.

\subsection{Distribution of publications to subjects and years}

The distribution of studies that included in the content analysis is shown in Table 3 , in terms of their subjects and years. According to Table 4, although the concept of sustainability emerged in 1987, no studies were conducted in the scope of sustainability in the ports between 1987 and 1997. The first study on port sustainability issues was published in 1998 and after that eight more studies published between the years of 1998 and 2007 which were examined in the scope of this study. After 2008, the importance given to the sustainability issue has increased, and a number of studies have been conducted on a variety of topics, primarily sustainable development, sustainability performance, and sustainable management concepts. 45 of these studies have been found directly related to the subject and examined within the scope of the study.

Table 3: Distribution of Research Subjects by Years

\begin{tabular}{|c|c|c|c|c|c|}
\hline Subject & $\begin{array}{c}1987 \\
\text { to } \\
1997\end{array}$ & $\begin{array}{c}1998 \\
\text { to } \\
2007\end{array}$ & $\begin{array}{c}2008 \\
\text { to } \\
2017\end{array}$ & Frequency & Percent \\
\hline Sustainable Development & - & 2 & 9 & 11 & 20,75 \\
\hline Sustainability Performance & - & - & 9 & 9 & 16,98 \\
\hline Sustainable Management & - & - & 8 & 8 & 15,09 \\
\hline Port Construction & - & 1 & 6 & 7 & 13,21 \\
\hline Environmental Sustainability & - & 1 & 4 & 5 & 9,43 \\
\hline Sustainability Indicators & - & 1 & 3 & 4 & 7,55 \\
\hline Sustainability Policy & - & 1 & 1 & 2 & 3,77 \\
\hline Sustainable Coastal Development & - & 1 & 1 & 2 & 3,77 \\
\hline $\begin{array}{l}\text { Economic and Environmental } \\
\text { Sustainability }\end{array}$ & - & - & 1 & 1 & 1,89 \\
\hline Ecological Footprint & - & - & 1 & 1 & 1,89 \\
\hline Social Sustainability & - & 1 & - & 1 & 1,89 \\
\hline Sustainability Reporting & - & - & 1 & 1 & 1,89 \\
\hline Sustainability Measurement & - & - & 1 & 1 & 1,89 \\
\hline Total & - & 8 & 45 & 53 & 100 \\
\hline
\end{tabular}


According to 53 studies' content analysis regarding to port sustainability subjects, the most common five subjects are sustainable development, sustainability performance, sustainable management, sustainable port construction and environmental sustainability respectively. The most common factor which is related to the sustainable development is stated in 11 studies. Details of other studies and subjects are given above Table 3. The distributions of the examined papers in terms of publishing years are shown in below Figure 1.

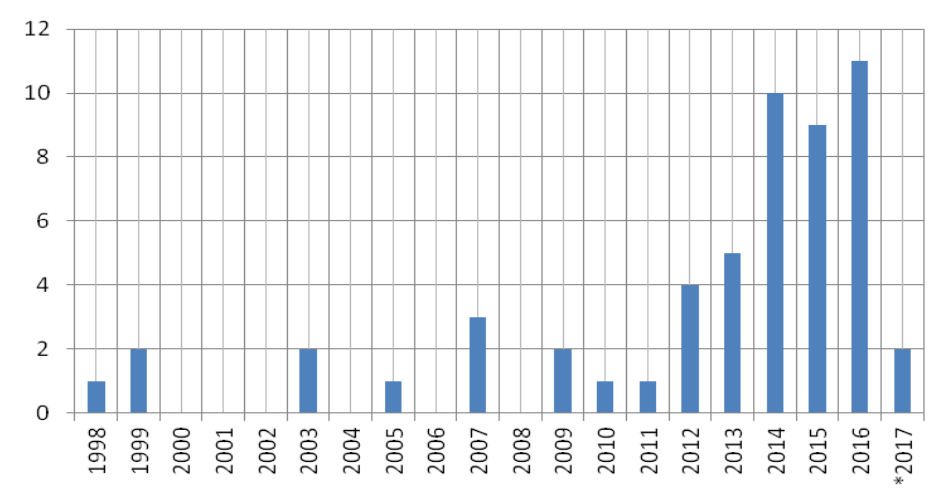

Figure 1: Number of Articles and Conference Proceedings Published per year between 1998 and 2017

* Values for 2017 include publications issued until April.

It should also be noted that, in the situation of that the examined study involves more than one subject listed in Table 3 the keyword rankings specified by the authors of the studies were taken into account. Hence studies included the subject with respect to their keywords.

\subsection{Distributions of publications to journals}

Table 4 demonstrates the lists and the distributions of the journals in which the studies published in the scope of content analysis. According to Table 4, 22,64\% of the studies consist of various conference proceedings. In accordance $77,36 \%$ of total studies consist of articles that published various journals. 4 articles that have $7,55 \%$ of total studies published in Marine Pollution Bulletin. Its followed by Transportation Research Procedia, Maritime Policy and Management, Research in Transportation Business \& Management, The Asian Journal of Shipping and Logistics, Marine Policy and Sustainability journals respectively. 20 articles' diverse journal names also listed in Table 4.

Table 4: Distribution of Studies to Journals

\begin{tabular}{lcc}
\hline \multicolumn{1}{c}{ Name of Journal } & Frequency & Percent \\
\hline Conference Proceedings & 12 & $22,64 \%$ \\
Marine Pollution Bulletin & 4 & $7,55 \%$ \\
Transportation Research Procedia & 3 & $5,66 \%$ \\
Maritime Policy \& Management & 3 & $5,66 \%$ \\
Research in Transportation Business \& Management & 2 & $3,77 \%$ \\
The Asian Journal of Shipping and Logistics & 2 & $3,77 \%$ \\
Marine Policy & 2 & $3,77 \%$ \\
Sustainability & 2 & $3,77 \%$ \\
Thermal Science & 1 & $1,89 \%$ \\
Open Journal of Social Sciences & 1 & $1,89 \%$ \\
Problems of Sustainable Development & 1 & $1,89 \%$ \\
Advanced Engineering Forum & 1 & $1,89 \%$ \\
\hline
\end{tabular}




\begin{tabular}{lcc}
\hline European Online Journal of Natural and Social Sciences & 1 & $1,89 \%$ \\
Procedia Social and Behavioral Sciences & 1 & $1,89 \%$ \\
Ocean \& Coastal Management & 1 & $1,89 \%$ \\
The Geographical Journal & 1 & $1,89 \%$ \\
Journal of Korea Port Economic Association & 1 & $1,89 \%$ \\
Journal of Transport Geography & 1 & $1,89 \%$ \\
Journal of Service Science and Management & 1 & $1,89 \%$ \\
Journal of Cleaner Production & 1 & $1,89 \%$ \\
International Journal of Architectural Research & 1 & $1,89 \%$ \\
Journal for Communication Studies & 1 & $1,89 \%$ \\
Journal of Mechanical Engineering & 1 & $1,89 \%$ \\
Journal of Black Sea Studies & 1 & $1,89 \%$ \\
International Journal of Sustainable Development & 1 & $1,89 \%$ \\
Transportation Research Part E & 1 & $1,89 \%$ \\
International Journal of Physical Distribution \& Logistics Management & 1 & $1,89 \%$ \\
Scientific Papers of the University of Pardubice Series D & 1 & $1,89 \%$ \\
Others (No info) & 3 & $5,66 \%$ \\
Total & 53 & $100,00 \%$ \\
\hline
\end{tabular}

\subsection{Distributions of publications to research methods}

Studies analyzed according to their research methods in the scope of the study. According to Table 5, 50,94\% of studies used quantitative research methods, $37,74 \%$ of them used qualitative research methods as a research method. In addition, $11,32 \%$ of total paper used both qualitative and quantitative research methods to reach their aims.

Table 5: Distribution of Studies to Research Methods

\begin{tabular}{lcc}
\hline Research Methods of Study & Frequency & Percent \\
\hline Quantitative Study & 27 & $50,94 \%$ \\
Qualitative Study & 20 & $37,74 \%$ \\
Qualitative and Quantitative & 6 & $11,32 \%$ \\
Total & 53 & $100,00 \%$ \\
\hline
\end{tabular}

\subsection{Distributions of publications according to methods used for analysis}

Data analysis methods of the papers were also analyzed in the scope of the study. Results are given in below Table 6. Case Study is the most frequent data analysis method in examined port sustainability studies with the ratio of $\% 29,85$. Literature review method was also used quite a lot, generally with the help of sustainability reports and annual reports of ports and current literature. Interview, MCDM (Multi Criteria Decision Making), Survey and Statistical Methods like SPSS, DEA, PDE and PSIR followed them respectively. In addition, just one paper found in literature that used Focus Group and Workshop methods.

Table 6: Distribution of Studies According to Methods Used for Analysis

\begin{tabular}{lcc}
\hline \multicolumn{1}{c}{ Methods Used for Analysis } & Frequency & Percent \\
\hline Case Study & 20 & $29,85 \%$ \\
Literature Review & 14 & $20,90 \%$ \\
Interview & 12 & $17,91 \%$ \\
MCDM (Multi Criteria Decision Making) & 9 & $13,43 \%$ \\
Survey & 7 & $10,45 \%$ \\
\hline
\end{tabular}




\begin{tabular}{lcc}
\hline Statistical Methods (SPSS, DEA, PDE, PSIR) & 4 & $5,97 \%$ \\
Focus Group and Workshop & 1 & $1,49 \%$ \\
Total & 67 & $100,00 \%$ \\
\hline
\end{tabular}

In addition, it is also identified that, 41 papers used just one method listed in Table 6, 9 studies used two different methods and 3 studies used three methods to reach their findings.

\section{Conclusion}

The importance given in sustainability issues increased significantly in recent decades. While the concept of sustainability emerged in 1987, no study was conducted in the scope of sustainability in the ports between 1987 and 1997. After 2008, the importance given to the sustainability issue has increased, and a number of studies have been conducted on a variety of topics. Although port sustainability issues come on the agenda in the last two decades, it is seen as one of the most important subjects in the sustainability concept due to the nature of the industry. In this direction, this study aimed to investigate current port sustainability literature in a systematic way.

First; the number of studies on port sustainability issues is quite limited compared to the number of studies on issues like "sustainable supply chain management" or "green port". In this direction, the results of the study demonstrated that there is still a significant gap in port sustainability issues and the emphasis should be given on port sustainability studies. When examined the 53 studies about ports sustainability subject in the current literature, it is determined that there exist very limited number of studies written about quite various fields. The most common five subjects are sustainable development, sustainability performance, sustainable management, sustainable port construction and environmental sustainability respectively. Addition to these subjects it is seen that there are neglected subjects like; sustainability policy, sustainable coastal development, economic and environmental sustainability, ecological footprint, social sustainability, sustainability reporting and sustainability measurement. It is thought that these neglected topics are quite important to the future studies. Especially sustainability reporting and sustainability measurement subjects should be studied in-depth and should also be developed to get more clear scores on sustainable performance indexes.

When the studies examined in terms of the methods they used, it was observed that they mainly focused on 6 methods, mainly case study, literature review and interview methods. The intense use of methods such as case study, literature review and interview, which are generally used to identify the current situation, is an important indicator of the fact that the concept is still in the process of development and it should continue to be studied. It is also seen that, MCDM methods used intensively in studies that examined sustainability measurement and sustainability indicators.

The study contains a list of major journals that publish ports sustainability studies. This list was created to provide a roadmap not only to authors who wish to obtain these studies but also to publish their port sustainability related studies to contribute to current literature.

The most important limitation of this study is the very limited number of publishing on port sustainability literature. Hence, it is suggested to the authors to carry out studies on issues that are found to be neglected like sustainability reporting and sustainability measurement in future studies.

\section{References}

[1] R. Bozlağan. Sosyal Siyaset Konferansları Dergisi, 50, 1011-1028 (2005).

[2] Ç. Aksoy. Marmara University Institute of Social Sciences (2013). 
[3] M. Taşçı̆̆lu. Georgia Southern University (2014).

[4] G. H. Brundtland. United Nations (1987).

[5] L. Sislian, A. Jaegler, and P. Cariou. Research in Transportation Business \&

Management, 19, 19-26. (2016).

[6] M. H. Hakam. Journal of Service science and Management, 8(01), 14 (2015).

https://file.scirp.org/pdf/JSSM 2015012211245289.pdf

[7] R. M. DARBRA. Marine pollution bulletin, 50.8: 866-874 (2005).

https://www.sciencedirect.com/science/article/pii/S0025326X05001918

[8] E. F. M. Broesterhuizen, T. Vellinga, L. Docters van Leeuwen, J. W. Zwakhals, P.

Taneja and M. Nijdam. CESUN2012, (2012).

https://www.researchgate.net/profile/Tiedo_Vellinga/publication/266051258

[9] M. Acciaro, H. Ghiara, and M. I. Cusano. Energy Policy, 71, 4-12 (2014).

https://www.sciencedirect.com/science/article/pii/S0301421514002262

[10] T. Daamen. In ENHR-conference, 25-28 (2007).

[11] K. A. Abood. In Ports 2007: 30 Years of Sharing Ideas: 1977-2007 (2007).

[12] J. S. L. Lam and E. Van de Voorde. International Forum on Shipping, Ports and Airports (IFSPA), 27-30 (2012).

[13] Y. C. E. Jonathan, Kader, A. S. A., bin Ahmad, Z., Mokhtar, I.

https://www.researchgate.net/profile/Jonathan_Yong_Chung_Ee/publication/269221509

[14] S. A. Hosseini, H. Amozad and M.K. Mafi. European Online Journal of Natural and Social Sciences, 3(3), 810 (2014).

[15] A. Kutkaitis, L. Šimanskiené and D. Burgis. Scientific Papers of the University of Pardubice. Series D, Faculty of Economics \& Administration, 21(30) (2014).

http://citeseerx.ist.psu.edu/viewdoc/download?doi=10.1.1.463.3768\&rep=rep1\&type=pdf\# page $=66$

[16] M. De Martino. In Advanced Engineering Forum Trans Tech Publications. 11, 87-95

(2014). https://www.scientific.net/AEF.11.87

[17] H. Wang, D. Huo and J. Ortiz. Open Journal of Social Sciences, 3(05), 28 (2015).

https://file.scirp.org/pdf/JSS_2015052016462023.pdf

[18] J. Boulos. Procedia-Social and Behavioral Sciences, 216, 974-985 (2016).

https://www.sciencedirect.com/science/article/pii/S1877042815062746

[19] F.G. Laxe, F.M. Bermúdez, F.M. Palmero and I. Novo-Corti. Marine pollution

bulletin, 113(1-2), 232-239 (2016).

https://www.sciencedirect.com/science/article/pii/S0025326X16307615

[20] S. Roh, V.V. Thai and Y.D. Wong. The Asian Journal of Shipping and

Logistics, 32(2), 107-118 (2016).

https://www.sciencedirect.com/science/article/pii/S2092521216300281

[21] M.H. Hakam and W.D. Solvang. SOLI'09. IEEE/INFORMS International Conference on IEEE 417-422 (2009). http://ieeexplore.ieee.org/abstract/document/5203969/

[22] M.H. Hakam and W.D. Solvang. Container ports sustainability-a literature review.

In Cognitive Infocommunications (CogInfoCom), 2013 IEEE 4th International Conference on IEEE 803-810 (2013). http://ieeexplore.ieee.org/abstract/document/6719209/

[23] T.C. Lirn, Y.C. Jim Wu and Y.J. Chen. International Journal of Physical Distribution \& Logistics Management, 43(5/6), 427-451 (2013).

https://www.emeraldinsight.com/doi/full/10.1108/IJPDLM-04-2012-0134

[24] S. Elzarka and S. Elgazzar. In International Forum on Shipping, Ports and Airports (IFSPA) (2014).

https://www.researchgate.net/profile/Sara_Elzarka2/publication/280385412

[25] N. Asgari, A. Hassani, D. Jones and H.H. Nguye. Transportation research part E:

logistics and transportation review, 78, 19-39 (2015).

https://www.sciencedirect.com/science/article/pii/S1366554515000150 
[26] C.S. Lu, K.C. Shang and C.C. Lin. Maritime Policy \& Management, 43(8), 909-927

(2016). https://www.tandfonline.com/doi/abs/10.1080/03088839.2016.1199918

[27] V. Çaglar. Karadeniz Arastirmalari, (49), 141 (2016).

https://search.proquest.com/docview/1788513671?pq-origsite=gscholar

[28] G. Denktas-Sakar and Ç. Karatas-Cetin. The Asian Journal of Shipping and

Logistics, 28(3), 301-319 (2012).

https://www.sciencedirect.com/science/article/pii/S2092521213000035

[29] S. Kim and B. Chiang. Sustainability Practices to achieve Sustainability in

International Port Operations. 30(3), 15-37 (2014).

[30] A. Fedai and C. Madran. II. Ulusal Liman Kongresi, (2015).

[31] L. Hou and H. Geerlings. Journal of Cleaner Production, 135, 449-456 (2016).

https://www.sciencedirect.com/science/article/pii/S0959652616308113

[32] X. Wang. A conceptual model for oil port sustainability policy research-A case of

Chinese ports. (2017).

[33] M. Dooms and C. Macharis. 43rd Congress of the European Regional Science

Association. (2003). https://www.econstor.eu/handle/10419/116041

[34] L.F. Girard. International Journal of Sustainable Development, 13(1-2), 161-184

(2010). https://www.inderscienceonline.com/doi/abs/10.1504/IJSD.2010.035106

[35] R. Wahab, T. Zayed, T. Goh and C.M. Wang. Proceedings of MTEC2011, 13, 15

(2011). https://www.researchgate.net/profile/Roshan_Wahab/publication/257418895

[36] N. Megahed. International Journal of Architectural Research: ArchNet-IJAR, 8(1), 94-

107 (2014). http://198.58.80.116/index.php/IJAR/article/view/299

[37] B. Pavlic, F. Cepak, B. Sucic, M. Peckaj and B. Kandus. Thermal Science, 18(3), 935948 (2014).

[38] S. Awad-Núñez, N. González-Cancelas, F. Soler-Flores and A. Camarero-Orive.

Transportation Research Procedia, 13, 124-133 (2016).

[39] B. Hoyle. Journal of Transport Geography, 7(1), 65-78 (1999).

https://www.sciencedirect.com/science/article/pii/S0966692398000301

[40] A.M. Vujicic, N. Zrnić and B. Jerman. Strojniški vestnik-Journal of Mechanical

Engineering, 59(9), 547-555 (2013). http://ojs.sv-jme.eu/index.php/sv-jme/article/view/svjme.2012.933

[41] J. Dinwoodie, A. Kuznetsov, D. Gibbs, M. Sansom and H. Knowles. Marine Policy 54, 59-68 (2013).

[42] F. Borriello. Sustainability, 5(10), 4288-4311 (2013). http://www.mdpi.com/2071$\underline{1050 / 5 / 10 / 4288 / \mathrm{htm}}$

[43] B. Beškovnik and P. Bajec. Problems of Sustainable Development.10 (1), 99-106

(2015). https://papers.ssrn.com/sol3/papers.cfm?abstract id=2556857

[44] D. Tanzil and B.R. Beloff. Environmental Quality Management, 15(4), 41-56 (2006).

[45] E. Peris-Mora, J.D. Orejas, A. Subirats, S. Ibáñez and P. Alvarez. Marine Pollution

Bulletin, 50(12), 1649-1660 (2005).

https://www.sciencedirect.com/science/article/pii/S0025326X05003048

[46] M. Puig, C. Wooldridge and R.M. Darbra. Marine pollution bulletin, 81(1), 124-130

(2014). https://www.sciencedirect.com/science/article/pii/S0025326X14000873

[47] A. Bergmans, F. Vandermoere and I. Loots.ESSACHESS-Journal for Communication

Studies, 7(1), 107-123 (2014). https://www.ssoar.info/ssoar/handle/document/40725

[48] T.A. Shiau and C.C. Chuang. Maritime Policy \& Management, 42(1), 26-42 (2015).

https://www.tandfonline.com/doi/abs/10.1080/03088839.2013.863436

[49] S. Gilman. Maritime Policy \& Management, 30(4), 275-291 (2003).

https://www.tandfonline.com/doi/abs/10.1080/0308883032000145591

[50] I. Kotowska. Transportation Research Procedia, 16, 236-243 (2016).

https://www.sciencedirect.com/science/article/pii/S2352146516306378 
[51] R.K. Turner, I. Lorenzoni, N. Beaumont, I.J. Bateman, I.H. Langford and A.L. McDonald. Geographical Journal, 269-281 (1998).

http://www.jstor.org/stable/3060616? seq=1\#page scan tab contents

[52] W.Y. Yap and J.S.L. Lam. Ocean \& coastal management, 71, 13-25 (2013).

https://www.sciencedirect.com/science/article/pii/S096456911200289X

[53] Tindall. Anti-Environmentalist Thinking About Change and Sustainability in Port Alberni. (1999).

[54] C.C. Soler, J.M.D. Orejas, A.G. Fillol and V.R. Feliu. Revue Sciences de Gestion, (70) (2009). http://eds.b.ebscohost.com/eds/detail/detail?vid=0\&sid=2c6c6a90-10db-4ce5-920b48f8b7e0af12\%40sessionmgr102\&bdata $=$ Jmxhbmc9dHImc210ZT11ZHMtbGl2ZSZzY29w ZT1zaXRl\#AN=47027958\&db=bth

[55] Z. J. Guo, Q. Zhang, W.Y. Wang and C. Wang. In Proceedings of the Eastern Asia Society for Transportation Studies (10) (2015).

https://pdfs.semanticscholar.org/9b3e/b6bd66b96af0fec998a8781da2267b21575e.pdf

[56] F. G. Laxe, F.M. Bermúdez, F.M. Palmero and I. Novo-Corti. Marine pollution bulletin, 113(1-2), 232-239 (2016).

https://www.sciencedirect.com/science/article/pii/S0025326X16307615

[57] Z. Xiao and J.S.L. Research in Transportation Business \& Management, 22, 255-262

(2017). https://www.sciencedirect.com/science/article/pii/S2210539516300694

[58] K. E. Rosengren. SAGE Publications, Incorporated. 9 (1981).

[59] R.P. Weber. Sage. (1990).

[60] F. L. Cole. Clinical Nurse Specialist 2(1), 53-57 (1988).

[61] Mayring, P. VS Verlag für Sozialwissenschaften. 601-603 (2010).

https://link.springer.com/chapter/10.1007/978-3-531-92052-8 42

[62] T.G. Harwood and T. Garry. The Marketing Review 3, 479-498 (2003)

[63] H. F. Hsieh and S.E. Shannon. Qualitative health research, 15(9), 1277-1288 (2005).

http://journals.sagepub.com/doi/abs/10.1177/1049732305276687

[64] T. Kuhlman and J. Farrington. Sustainability, 2(11), 3436-3448 (2010). 


\begin{tabular}{|c|c|c|c|c|c|c|}
\hline \multicolumn{7}{|c|}{ Appendix: Details of the Reviewed Studies } \\
\hline No & Name of Study & Author & Year & $\begin{array}{c}\text { Research } \\
\text { Method }\end{array}$ & Method & Subject \\
\hline 1 & $\begin{array}{l}\text { Coastal Management for } \\
\text { Sustainable Development: } \\
\text { Analyzing Environmental and } \\
\text { Socio-Economic Changes on the } \\
\text { UK Coast }\end{array}$ & $\begin{array}{l}\text { Turner et } \\
\text { al. }\end{array}$ & 1998 & Quantitative & $\begin{array}{l}\text { Statistical } \\
\text { Methods }\end{array}$ & $\begin{array}{c}\text { Sustainable } \\
\text { Coastal } \\
\text { Development }\end{array}$ \\
\hline 2 & $\begin{array}{l}\text { Anti-Environmentalist Thinking } \\
\text { About Change and Sustainability } \\
\text { in Port Alberni }\end{array}$ & Tindall & 1999 & Quantitative & Survey & $\begin{array}{c}\text { Social } \\
\text { Sustainability }\end{array}$ \\
\hline 3 & $\begin{array}{l}\text { Scale And Sustainability: The } \\
\text { Role of Community Groups in } \\
\text { Canadian Port-City Waterfront } \\
\text { Change }\end{array}$ & Hoyle & 1999 & Qualitative & Interview & $\begin{array}{l}\text { Environmental } \\
\text { Sustainability }\end{array}$ \\
\hline 4 & $\begin{array}{l}\text { Sustainability and National } \\
\text { Policy in UK Port Development }\end{array}$ & Gilman & 2003 & Qualitative & $\begin{array}{l}\text { Literature } \\
\text { Review }\end{array}$ & $\begin{array}{l}\text { Sustainability } \\
\text { Policy }\end{array}$ \\
\hline 5 & $\begin{array}{l}\text { A Framework for Sustainable } \\
\text { Port Planning in Inland Ports: A } \\
\text { Multi Stakeholder Approach }\end{array}$ & $\begin{array}{l}\text { Dooms } \\
\text { and } \\
\text { Macharis }\end{array}$ & 2003 & $\begin{array}{l}\text { Quantitative } \\
\text { and } \\
\text { Qualitative }\end{array}$ & $\begin{array}{l}\text { MCDM/ } \\
\text { Interview }\end{array}$ & $\begin{array}{c}\text { Port } \\
\text { Construction }\end{array}$ \\
\hline 6 & $\begin{array}{l}\text { Development of a System of } \\
\text { Indicators for Sustainable Port } \\
\text { Management }\end{array}$ & $\begin{array}{l}\text { Peris- } \\
\text { Mora et } \\
\text { al. }\end{array}$ & 2005 & Quantitative & $\begin{array}{l}\text { MCDM/ } \\
\text { Case } \\
\text { Study }\end{array}$ & $\begin{array}{l}\text { Sustainability } \\
\text { Indicators }\end{array}$ \\
\hline 7 & $\begin{array}{l}\text { Sustainable and Green Ports: } \\
\text { Application of Sustainability } \\
\text { Principles to Port Development } \\
\text { and Operation }\end{array}$ & Abood & 2007 & Quantitative & $\begin{array}{l}\text { Case } \\
\text { Study }\end{array}$ & $\begin{array}{c}\text { Sustainable } \\
\text { Development }\end{array}$ \\
\hline 8 & $\begin{array}{l}\text { Sustainable Development of The } \\
\text { European Port-City Interface }\end{array}$ & Daamen & 2007 & Qualitative & $\begin{array}{l}\text { Literature } \\
\text { Review }\end{array}$ & $\begin{array}{c}\text { Sustainable } \\
\text { Development }\end{array}$ \\
\hline 9 & $\begin{array}{l}\text { Sustainability Reports as a Key } \\
\text { Tool for Communication } \\
\text { Improvement in the Spanish Port } \\
\text { System }\end{array}$ & $\begin{array}{l}\text { Soler et } \\
\text { al. }\end{array}$ & 2009 & Qualitative & $\begin{array}{l}\text { Literature } \\
\text { Review }\end{array}$ & $\begin{array}{l}\text { Sustainability } \\
\text { Reporting }\end{array}$ \\
\hline 10 & $\begin{array}{l}\text { On Flexibility and Sustainability } \\
\text { in Container Ports }\end{array}$ & $\begin{array}{l}\text { Hakam } \\
\text { and } \\
\text { Solvang }\end{array}$ & 2009 & Quantitative & $\begin{array}{l}\text { Case } \\
\text { Study }\end{array}$ & $\begin{array}{l}\text { Sustainability } \\
\text { Performance }\end{array}$ \\
\hline 11 & $\begin{array}{l}\text { Sustainability, Creativity, } \\
\text { Resilience: Toward New } \\
\text { Development Strategies of Port }\end{array}$ & Girard & 2010 & Quantitative & MCDM & $\begin{array}{c}\text { Port } \\
\text { Construction }\end{array}$ \\
\hline
\end{tabular}




\begin{tabular}{|c|c|c|c|c|c|c|}
\hline & $\begin{array}{l}\text { Areas Through Evaluation } \\
\text { Processes }\end{array}$ & & & & & \\
\hline 12 & $\begin{array}{l}\text { Sustainability and } \\
\text { Maintainability of Port } \\
\text { Infrastructure Using BIM/4D } \\
\text { CAD Simulation Model }\end{array}$ & $\begin{array}{l}\text { Wahab et } \\
\text { al. }\end{array}$ & 2011 & Quantitative & $\begin{array}{l}\text { MCDM/ } \\
\text { Survey/ } \\
\text { Case } \\
\text { Study }\end{array}$ & $\begin{array}{c}\text { Port } \\
\text { Construction }\end{array}$ \\
\hline 13 & $\begin{array}{l}\text { Port Sustainability and } \\
\text { Stakeholder Management in } \\
\text { Supply Chains: A Framework on } \\
\text { Resource Dependence Theory }\end{array}$ & $\begin{array}{l}\text { Denktaş- } \\
\text { Şakar and } \\
\text { Karataş- } \\
\text { Çetin }\end{array}$ & 2012 & Qualitative & $\begin{array}{l}\text { Literature } \\
\text { Review }\end{array}$ & $\begin{array}{l}\text { Sustainable } \\
\text { Management }\end{array}$ \\
\hline 14 & $\begin{array}{l}\text { Sustainability as a Procurement } \\
\text { Criterion for Port Investments }\end{array}$ & $\begin{array}{l}\text { Broesterh } \\
\text { uisen et } \\
\text { al. }\end{array}$ & 2012 & Qualitative & Interview & $\begin{array}{l}\text { Sustainable } \\
\text { Management }\end{array}$ \\
\hline 15 & $\begin{array}{l}\text { Ports Sustainability: A Life Cycle } \\
\text { Assessment of Zero Emission } \\
\text { Cargo Handling Equipment }\end{array}$ & $\begin{array}{l}\text { Vujicic et } \\
\text { al. }\end{array}$ & 2012 & Quantitative & $\begin{array}{l}\text { Case } \\
\text { Study }\end{array}$ & $\begin{array}{r}\text { Environmental } \\
\text { Sustainability }\end{array}$ \\
\hline 16 & $\begin{array}{l}\text { Green Port Strategy for } \\
\text { Sustainable Growth and } \\
\text { Development }\end{array}$ & $\begin{array}{l}\text { Lam and } \\
\text { Van de } \\
\text { Voorde }\end{array}$ & 2012 & Quantitative & $\begin{array}{l}\text { Case } \\
\text { Study }\end{array}$ & $\begin{array}{c}\text { Sustainable } \\
\text { Development }\end{array}$ \\
\hline 17 & $\begin{array}{l}\text { Towards a Port Sustainability } \\
\text { Management System for Smaller } \\
\text { Ports }\end{array}$ & $\begin{array}{l}\text { Dinwoodie } \\
\text { et al. }\end{array}$ & 2013 & Qualitative & Interview & $\begin{array}{l}\text { Environmental } \\
\text { Sustainability }\end{array}$ \\
\hline 18 & $\begin{array}{l}\text { Green Performance Criteria for } \\
\text { Sustainable Ports in Asia }\end{array}$ & Lirn et al. & 2013 & Quantitative & MCDM & $\begin{array}{l}\text { Sustainability } \\
\text { Performance }\end{array}$ \\
\hline 19 & $\begin{array}{l}\text { Container Ports Sustainability: A } \\
\text { Literature Review }\end{array}$ & $\begin{array}{c}\text { Hakam } \\
\text { and } \\
\text { Solvang }\end{array}$ & 2013 & Qualitative & $\begin{array}{l}\text { Literature } \\
\text { Review }\end{array}$ & $\begin{array}{l}\text { Sustainability } \\
\text { Performance }\end{array}$ \\
\hline 20 & $\begin{array}{l}\text { The Sustainability of } \\
\text { Mediterranean Port Areas: } \\
\text { Environmental Management for } \\
\text { Local Regeneration in Valencia }\end{array}$ & $\begin{array}{l}\text { Borriello } \\
\text { et al. }\end{array}$ & 2013 & Quantitative & $\begin{array}{l}\text { Case } \\
\text { Study }\end{array}$ & $\begin{array}{r}\text { Environmental } \\
\text { Sustainability }\end{array}$ \\
\hline 21 & $\begin{array}{l}80 \text { Million-Twenty-Foot- } \\
\text { Equivalent-Unit Container Port? } \\
\text { Sustainability Issues in Port and } \\
\text { Coastal Development }\end{array}$ & $\begin{array}{l}\text { Yap and } \\
\text { Lam }\end{array}$ & 2013 & Qualitative & $\begin{array}{l}\text { Literature } \\
\text { Review }\end{array}$ & $\begin{array}{l}\text { Sustainable } \\
\text { Coastal } \\
\text { Development }\end{array}$ \\
\hline 22 & $\begin{array}{l}\text { Sustainability Practices to } \\
\text { Achieve Sustainability in } \\
\text { International Port Operations }\end{array}$ & $\begin{array}{l}\text { Kim and } \\
\text { Chiang }\end{array}$ & 2014 & Qualitative & Interview & $\begin{array}{c}\text { Sustainable } \\
\text { Management }\end{array}$ \\
\hline
\end{tabular}




\begin{tabular}{|c|c|c|c|c|c|c|}
\hline 23 & $\begin{array}{l}\text { Sustainable Port Infrastructure, } \\
\text { Practical Implementation of the } \\
\text { Green Port Concept }\end{array}$ & $\begin{array}{c}\text { Pavlic et } \\
\text { al. }\end{array}$ & 2014 & Quantitative & $\begin{array}{l}\text { Case } \\
\text { Study }\end{array}$ & $\begin{array}{c}\text { Port } \\
\text { Construction }\end{array}$ \\
\hline 24 & $\begin{array}{l}\text { Green Port Performance Index } \\
\text { For Sustainable Ports in Egypt: A } \\
\text { Fuzzy AHP Approach }\end{array}$ & $\begin{array}{l}\text { Elzarka } \\
\text { and } \\
\text { Elgazzar }\end{array}$ & 2014 & Quantitative & $\begin{array}{l}\text { MDCM/ } \\
\text { Survey }\end{array}$ & $\begin{array}{l}\text { Sustainability } \\
\text { Performance }\end{array}$ \\
\hline 25 & $\begin{array}{l}\text { Identification and Selection of } \\
\text { Environmental Performance } \\
\text { Indicators for Sustainable Port } \\
\text { Development }\end{array}$ & Puig et al. & 2014 & $\begin{array}{l}\text { Quantitative } \\
\text { and } \\
\text { Qualitative }\end{array}$ & $\begin{array}{c}\text { Survey/ } \\
\text { Focus } \\
\text { Group/ } \\
\text { Workshop }\end{array}$ & $\begin{array}{l}\text { Sustainability } \\
\text { Indicators }\end{array}$ \\
\hline 26 & $\begin{array}{l}\text { Heritage-Based Sustainability in } \\
\text { Port Said: Classification of Styles } \\
\text { and Future Development }\end{array}$ & Megahead & 2014 & Qualitative & Interview & $\begin{array}{c}\text { Port } \\
\text { Construction }\end{array}$ \\
\hline 27 & $\begin{array}{l}\text { Co-Producing Sustainability } \\
\text { Indicators for the Port of } \\
\text { Antwerp: How Sustainability } \\
\text { Reporting Creates New } \\
\text { Discursive Spaces for Concern } \\
\text { and Mobilization }\end{array}$ & $\begin{array}{c}\text { Bergmans } \\
\text { et al. }\end{array}$ & 2014 & Quantitative & $\begin{array}{l}\text { Case } \\
\text { Study }\end{array}$ & $\begin{array}{c}\text { Sustainability } \\
\text { Indicators }\end{array}$ \\
\hline 28 & $\begin{array}{l}\text { Assessment of Sustainability of } \\
\text { Logistic Activity of Port of } \\
\text { Klaipeda }\end{array}$ & $\begin{array}{c}\text { Kutkaitis } \\
\text { et al. }\end{array}$ & 2014 & Qualitative & Interview & $\begin{array}{l}\text { Sustainable } \\
\text { Development }\end{array}$ \\
\hline 29 & $\begin{array}{l}\text { Green and Sustainable Port } \\
\text { Project Planning: Paradigm Shift } \\
\text { for an Integrated Container } \\
\text { Handling System Expansion }\end{array}$ & $\begin{array}{c}\text { Jonathan } \\
\text { et al. }\end{array}$ & 2014 & Qualitative & $\begin{array}{c}\text { Literature } \\
\text { Review }\end{array}$ & $\begin{array}{l}\text { Sustainable } \\
\text { Development }\end{array}$ \\
\hline 30 & $\begin{array}{l}\text { Planning of Sustainable } \\
\text { Development Based on Civil } \\
\text { Rights in Torkaman Port }\end{array}$ & $\begin{array}{l}\text { Lam and } \\
\text { Van de } \\
\text { Voorde }\end{array}$ & 2014 & Quantitative & Survey & $\begin{array}{l}\text { Sustainable } \\
\text { Development }\end{array}$ \\
\hline 31 & $\begin{array}{l}\text { Sustainable Development } \\
\text { Strategies of the Port Authority: } \\
\text { The Network Approach }\end{array}$ & Martino & 2014 & Qualitative & $\begin{array}{c}\text { Literature } \\
\text { Review }\end{array}$ & $\begin{array}{l}\text { Sustainable } \\
\text { Development }\end{array}$ \\
\hline 32 & $\begin{array}{l}\text { Nordic Container Port } \\
\text { Sustainability Performance: A } \\
\text { Conceptual Intelligent } \\
\text { Framework }\end{array}$ & Hakam & 2015 & Qualitative & $\begin{array}{c}\text { Literature } \\
\text { Review }\end{array}$ & $\begin{array}{l}\text { Sustainability } \\
\text { Performance }\end{array}$ \\
\hline 33 & $\begin{array}{l}\text { Sürdürülebilir Liman Yönetimi } \\
\text { ve Antalya'da İki Yat Limaninda } \\
\text { Vaka İncelemesi }\end{array}$ & $\begin{array}{c}\text { Fedai and } \\
\text { Madran }\end{array}$ & 2015 & Quantitative & $\begin{array}{l}\text { Case } \\
\text { Study }\end{array}$ & $\begin{array}{l}\text { Sustainable } \\
\text { Management }\end{array}$ \\
\hline
\end{tabular}




\begin{tabular}{|c|c|c|c|c|c|c|}
\hline 34 & $\begin{array}{l}\text { Sustainable Development of } \\
\text { Coastal Cities-Proposal of a } \\
\text { Modelling Framework to } \\
\text { Achieve Sustainable City-Port } \\
\text { Connectivity }\end{array}$ & Boulos & 2015 & Quantitative & $\begin{array}{l}\text { Case } \\
\text { Study }\end{array}$ & $\begin{array}{c}\text { Sustainable } \\
\text { Development }\end{array}$ \\
\hline 35 & $\begin{array}{l}\text { Assessing Energy Efficiency of } \\
\text { Port Operations in China: A Case } \\
\text { Study on Sustainable } \\
\text { Development of Green Ports }\end{array}$ & $\begin{array}{c}\text { Wang et } \\
\text { al. }\end{array}$ & 2015 & Quantitative & $\begin{array}{l}\text { Statistical } \\
\text { Methods }\end{array}$ & $\begin{array}{c}\text { Sustainable } \\
\text { Development }\end{array}$ \\
\hline 36 & $\begin{array}{l}\text { Application of Environmental } \\
\text { and Social Sustainable Measures } \\
\text { by Port of Koper: The Basis for } \\
\text { the Regional Approach }\end{array}$ & $\begin{array}{l}\text { Beskovnik } \\
\text { and Bajec }\end{array}$ & 2015 & Quantitative & $\begin{array}{l}\text { Case } \\
\text { Study }\end{array}$ & $\begin{array}{l}\text { Environmental } \\
\text { Sustainability }\end{array}$ \\
\hline 37 & $\begin{array}{l}\text { Using Ecological Footprint } \\
\text { Model for Port Ecosystem } \\
\text { Sustainability Assessment }\end{array}$ & Guo et al. & 2015 & Qualitative & $\begin{array}{l}\text { Case } \\
\text { Study }\end{array}$ & $\begin{array}{l}\text { Ecological } \\
\text { Footprint }\end{array}$ \\
\hline 38 & $\begin{array}{l}\text { Towards a Sustainability } \\
\text { Management System for Smaller } \\
\text { Ports }\end{array}$ & $\begin{array}{c}\text { Kuznetsov } \\
\text { et al. }\end{array}$ & 2015 & $\begin{array}{l}\text { Qualitative } \\
\text { and } \\
\text { Quantitative }\end{array}$ & $\begin{array}{l}\text { Interview/ } \\
\text { Case } \\
\text { Study }\end{array}$ & $\begin{array}{c}\text { Sustainable } \\
\text { Management }\end{array}$ \\
\hline 39 & $\begin{array}{l}\text { Sustainability Ranking of the UK } \\
\text { Major Ports: Methodology and } \\
\text { Case Study }\end{array}$ & $\begin{array}{c}\text { Asgari et } \\
\text { al. }\end{array}$ & 2015 & Quantitative & MCDM & $\begin{array}{l}\text { Sustainability } \\
\text { Performance }\end{array}$ \\
\hline 40 & $\begin{array}{l}\text { Social Construction of Port } \\
\text { Sustainability Indicators: A Case } \\
\text { Study of Keelung Port }\end{array}$ & $\begin{array}{c}\text { Shiau and } \\
\text { Chuang }\end{array}$ & 2015 & $\begin{array}{l}\text { Quantitative } \\
\text { and } \\
\text { Qualitative }\end{array}$ & $\begin{array}{c}\text { Interview/ } \\
\text { Case } \\
\text { Study }\end{array}$ & $\begin{array}{l}\text { Sustainability } \\
\text { Indicators }\end{array}$ \\
\hline 41 & $\begin{array}{l}\text { Sustainability and the Spanish } \\
\text { Port System. Analysis of the } \\
\text { Relationship Between Economic } \\
\text { and Environmental Indicators }\end{array}$ & Laxe et al. & 2016 & Quantitative & $\begin{array}{l}\text { Statistical } \\
\text { Methods }\end{array}$ & $\begin{array}{l}\text { Economic and } \\
\text { Environmental } \\
\text { Sustainability }\end{array}$ \\
\hline 42 & $\begin{array}{l}\text { Dynamics in Sustainable Port and } \\
\text { Hinterland Operations: A } \\
\text { Conceptual Framework and } \\
\text { Simulation of Sustainability } \\
\text { Measures and Their } \\
\text { Effectiveness, Based on an } \\
\text { Application to the Port of } \\
\text { Shanghai }\end{array}$ & $\begin{array}{l}\text { Hou and } \\
\text { Geerlings }\end{array}$ & 2016 & $\begin{array}{l}\text { Quantitative } \\
\text { and } \\
\text { Qualitative }\end{array}$ & $\begin{array}{l}\text { Literature } \\
\text { Review/ } \\
\text { Interview/ } \\
\text { Case } \\
\text { Study }\end{array}$ & $\begin{array}{l}\text { Sustainable } \\
\text { Management }\end{array}$ \\
\hline 43 & $\begin{array}{l}\text { A Literature Review on Port } \\
\text { Sustainability and Ocean's } \\
\text { Carrier Network Problem }\end{array}$ & $\begin{array}{c}\text { Sislian et } \\
\text { al. }\end{array}$ & 2016 & Qualitative & $\begin{array}{l}\text { Literature } \\
\text { Review }\end{array}$ & $\begin{array}{c}\text { Sustainable } \\
\text { Management }\end{array}$ \\
\hline
\end{tabular}




\begin{tabular}{|c|c|c|c|c|c|c|}
\hline 44 & $\begin{array}{l}\text { Examining Sustainability } \\
\text { Performance at Ports: Port } \\
\text { Managers' Perspectives on } \\
\text { Developing Sustainable Supply } \\
\text { Chains }\end{array}$ & Lu et al. & 2016 & Quantitative & Survey & $\begin{array}{l}\text { Sustainability } \\
\text { Performance }\end{array}$ \\
\hline 45 & $\begin{array}{l}\text { Sustainable Container Terminal } \\
\text { Operations: Challenges and } \\
\text { Enhancements }\end{array}$ & Çağlar & 2016 & $\begin{array}{l}\text { Quantitative } \\
\text { and } \\
\text { Qualitative }\end{array}$ & $\begin{array}{l}\text { Interview/ } \\
\text { Survey }\end{array}$ & $\begin{array}{l}\text { Sustainability } \\
\text { Performance }\end{array}$ \\
\hline 46 & $\begin{array}{l}\text { Assessment of Port Sustainability } \\
\text { Through Synthetic Indexes: An } \\
\text { Application to the Spanish Case }\end{array}$ & Laxe et al. & 2016 & Quantitative & $\begin{array}{l}\text { Statistical } \\
\text { Methods }\end{array}$ & $\begin{array}{c}\text { Sustainable } \\
\text { Development }\end{array}$ \\
\hline 47 & $\begin{array}{l}\text { A Methodology for Measuring } \\
\text { Sustainability of Dry Ports } \\
\text { Location Based on Bayesian } \\
\text { Networks and Multi-Criteria } \\
\text { Decision Analysis }\end{array}$ & $\begin{array}{l}\text { Awad- } \\
\text { Nunez et } \\
\text { al. }\end{array}$ & 2016 & Quantitative & $\begin{array}{l}\text { MCDM/ } \\
\text { Case } \\
\text { Study }\end{array}$ & $\begin{array}{c}\text { Port } \\
\text { Construction }\end{array}$ \\
\hline 48 & $\begin{array}{l}\text { How Should the Sustainability of } \\
\text { the Location of Dry Ports Be } \\
\text { Measured? }\end{array}$ & $\begin{array}{l}\text { Awad- } \\
\text { Nunez et } \\
\text { al. }\end{array}$ & 2016 & Quantitative & $\begin{array}{l}\text { MCDM/ } \\
\text { Case } \\
\text { Study }\end{array}$ & $\begin{array}{c}\text { Port } \\
\text { Construction }\end{array}$ \\
\hline 49 & $\begin{array}{l}\text { Functional Differentiation and } \\
\text { Sustainability: A New Stage of } \\
\text { Development in the Chinese } \\
\text { Container Port System }\end{array}$ & $\begin{array}{c}\text { Wang et } \\
\text { al. }\end{array}$ & 2016 & Qualitative & $\begin{array}{c}\text { Literature } \\
\text { Review }\end{array}$ & $\begin{array}{l}\text { Sustainability } \\
\text { Performance }\end{array}$ \\
\hline 50 & $\begin{array}{l}\text { Towards Sustainable ASEAN } \\
\text { Port Development: Challenges } \\
\text { and Opportunities for Vietnamese } \\
\text { Ports }\end{array}$ & Roh et al. & 2016 & Qualitative & $\begin{array}{l}\text { Interview/ } \\
\text { Literature } \\
\text { Review }\end{array}$ & $\begin{array}{c}\text { Sustainable } \\
\text { Development }\end{array}$ \\
\hline 51 & $\begin{array}{l}\text { Policies Applied by Seaport } \\
\text { Authorities to Create Sustainable } \\
\text { Development in Port Cities }\end{array}$ & Kotowska & 2016 & Quantitative & $\begin{array}{l}\text { Case } \\
\text { Study }\end{array}$ & $\begin{array}{c}\text { Sustainability } \\
\text { Policy }\end{array}$ \\
\hline 52 & $\begin{array}{l}\text { A Conceptual Model for Oil Port } \\
\text { Sustainability Policy Research: A } \\
\text { Case Study of Chinese Ports }\end{array}$ & $\begin{array}{c}\text { Wang et } \\
\text { al. }\end{array}$ & 2017 & Qualitative & $\begin{array}{c}\text { Literature } \\
\text { Review }\end{array}$ & $\begin{array}{c}\text { Sustainable } \\
\text { Management }\end{array}$ \\
\hline 53 & $\begin{array}{l}\text { A Systems Framework for the } \\
\text { Sustainable Development of a } \\
\text { Port City: A Case Study of } \\
\text { Singapore's Policies }\end{array}$ & $\begin{array}{l}\text { Xiao and } \\
\text { Lam }\end{array}$ & 2017 & Quantitative & $\begin{array}{l}\text { Case } \\
\text { Study }\end{array}$ & $\begin{array}{l}\text { Sustainability } \\
\text { Measurement }\end{array}$ \\
\hline
\end{tabular}

